http://dx.doi.org/10.18778/8142-006-8.09

\title{
TRANSGRESSING THE SPACES IN FILM ADAPTATION of W. SOMERSET MAUGHAM's THE PAINTED VEIL
}

\section{AGNIESZKA KURZAWA}

The question whether an uncrossable gulf between female and male spaces exists or not, arises not only in terms of literal spaces but in terms of metaphorical ones as well. In other words, the metaphorical space consists of one's understanding of the world, their response to it, and correspondingly, it encompasses what influence the world exerts upon them. Interestingly, it may seem that the space which is limited by one's personality or the social position they occupy is more difficult to transgress than the one determined by the literal enclosure of four walls surrounding a particular area. An individual who has a definite feeling of attachment towards their own physical and emotional space can be presumably less eager to share it, and, unconsciously he or she aims at partial or even complete exclusion from others, thus, remaining their own space to be inviolate. There are, however, at least two instances in which transgression seems unavoidable. Namely, having some degree of uncertainty or a need for expansion, one can abandon their own space and claim the other, or one can simply embrace the other space and derive some benefits from it, consequently inhabiting their own anew.

All these transgressions between both literal and metaphorical spheres can be abundantly observed in the figures of Kitty Fane (Naomi Watts) and Walter Fane (Edward Norton), the protagonists of the latest film adaptation of the novel written by W. Somerset Maugham The Painted Veil. Released in 2006, the film tells the story of an unhappily married couple who in 1920s moves from London to Shanghai where Walter works as a bacteriologist in a government lab. It is he who loves his wife deeply, although being aware of the flaws in her character, namely selfishness and frivolity. In one scene, he openly admits to her:

I knew when I married you that you were selfish and spoiled. But I loved you. I knew you only married me to get as far away from your mother as possible... And I hoped that one day there'd be something more. 
In fact, their misfortune stems from Kitty's being unable to truly appreciate her husband, for her assessment of his personality is also rather far from optimistic. She considers him as being a relentless bore whose life revolves primarily around books and intellectual pursuits which she neither understands nor values. Therefore, she contributes substantially to the animosity between them by committing adultery, the result of which is Walter's decision of their moving to southern China fraught with revolutionary unrest and an epidemic of cholera. It is only in Mei-tan-fu where they embark on uneasy coexistence and, paradoxically, such unfavourable conditions lead to their reunion. Unlike in the novel where Kitty never fully accepts Walter, the film provides an ample opportunity for their relationship to develop. Therefore, being in a substantial contrast with the book, the film needs to be examined in detail, especially giving the reasons for which this development as well as Kitty's transformation may take place.

In this paper, I am going to explore the extent to which both female and male spaces influence each other and what can be inferred from their being juxtaposed. Firstly, it is Walter who nearly enters the room where his wife has a clandestine meeting with her lover though he decides not to eventually. This does not mean, however, that he was unaware of the betrayal, rather that he already at that stage consciously isolates himself from the space of his unfaithful wife. Secondly, for Kitty, the male space, which is her husband's work and he himself, seems to be impenetrable, thus, resulting in her total exclusion from him. Furthermore, when residing in Mei-tan-fu, she encounters her confinement on many levels, not only with regard to her husband but also to the world surrounding her. On a larger scale, the female protagonist is separated from the outside world by the physical distance from civilisation, the cholera which infects the place, a guard who follows her wherever she goes and, most importantly, she is separated from her true self, for she has to reconcile with the unrequited love and acknowledge a current situation imposed upon her by her vengeful husband. Finally, the female protagonist allows herself to enter another women's space and, at the same time, she embraces it to her own advantage. Thus, becoming acquainted with nuns and, then, undertaking work at the convent greatly contribute to Kitty's gradual transformation.

When taking into consideration the first instance of transgressing space in the film, one meets the character of Walter Fane who simultaneously exemplifies both literal and metaphorical confinement. Since the male protagonist appears as rather taciturn and dominant, he involuntarily excludes others from himself. Consequently, he acts as an introvert husband whose need for the utter seclusion due to his professional work invites his wife to 
enter into an illicit love affair. Therefore, it is tempting to assume that if it was not for Walter's disposition and the barrier he creates, his wife would not fall into the arms of the debonair charmer. Undoubtedly, Walter's gloominess can be partly justified by the kind of profession he practises, however, it is also partly the result of his discouragement as Kitty, from the very beginning, considers his work abstract and altogether tedious. Their mutual incompatibility is the reason which impels his wife to commit such an ignominious act. What is even more dramatic, Walter becomes the eyewitness of it, to the horror of the two lovers who are oblivious to the world around them. Most importantly, however, it is vital to note that when Walter discovers the scene of betrayal, he does not open the door, quite the contrary, at the moment when he acknowledges what happens behind these doors, he silently walks away. Surely, it may suggest that Walter is rather of a weak character, however, he does not act hastily but takes revenge on his wife when the time is right. Ultimately, his confinement is twofold: he resolves not to intrude into the room, being literally separated from his wife and, consequently, he does not allow her to infringe his own space as he initially confines himself in it during their stay in Mei-tan-fu.

The abundant instances of various transgressions between both female and male spaces are embodied in the female protagonist of The Painted Veil. In Shanghai, she is excluded from her husband, whom she neither loves nor understands, and then in Mei-tan-fu, she also is condemned to the confinement not only by her inapproachable husband but also by the Chinese guard who, instead of protecting her, limits her already cramped freedom by following wherever she goes. Despite both metaphorical and literal spaces which restrict her to a great extent, Kitty is able to find a way out, nevertheless. It is at the convent where she embarks on voluntary work under the guidance of the nuns that she most importantly embraces their space in order to redefine her own. Therefore, it may prove that only when Kitty resolves on letting the spiritual enter her sphere, does she acknowledge her personality and a calling to be a mother.

When Walter meets Kitty for the first time, he is captivated exclusively by her beauty and charm, for her character does not weigh in her favour: she is rather shallow, frivolous, and indulgent. Despite such obvious blemishes, he is determined to marry her all the same. Kitty, on her part, is desperate to leave her insufferable mother, thus, she consents to Walter's marriage proposal, knowing that a scientist whose work has no great importance to her is but an escape from spinsterhood. From the very beginning, she is entirely separated from her husband's passions and interests as she herself possesses none. Indubitably, there exists an unbridgeable gap between the two since both Walter and Kitty inhabit two separate spaces which neither of them wish 
to share or abandon. He indulges himself in science, she indulges herself in her every whim. Such a combination of these two opposite poles combined together may appear as a contradiction in terms, but as it also later proves, they could not be more dependent upon each other. Indeed, it mistakenly seems that this state of affairs will permanently prevail during their journey to the heart of the plaque where supposedly only death should await them. On the contrary, it is in fact in Mei-tan-fu where they gradually exit their comfortable spaces and open up for each other.

In the region seething with revolutionary tensions, Kitty surprisingly finds the place which brings not only refreshment to her soul but reconciliation with her husband as well. The nuns who take care of underprivileged orphans inspire the female protagonist to undertake a task of helping them. It surely provides her flagging spirit with a completely new experience, since for the first time in her life Kitty sacrifices herself for others. After seeing how dedicated and remarkably calm the nuns are in the face of a deadly epidemic, Kitty begins to acknowledge the flaws in her own demeanour. This is especially significant in terms of transgressing another space because as in Walter's case, she again is faintly familiar with their work and spiritual insights. Nonetheless, owing to their austere way of life, hard work, and faith, Kitty gains a great appreciation for them and willingness to embrace their confined space. Interestingly, it is especially highlighted in the novel in the following words,

It was as though the corner of a curtain were lifted for a moment, and she caught a glimpse of a world rich with a colour and significance she had not dreamt of. (Maugham 31)

When she commits herself to helping destitute orphans and enters other women's space, she can gradually flourish, and unveil both this "rich world" and, thanks to it, her true inner self, potential of the existence of which she was unaware. This, therefore, utterly transforms both her perspective of the world and her assessment of herself: she becomes less self-centred so as to acknowledge her quilt and injustice she caused for her devoted husband. Notably, as Rohan Maitzen rightly puts it in his article, "she doesn't really experience one single epiphanic moment; her change is gradual and only tentatively religious." Indeed, it is the spirituality of the nuns which exerts a profound influence on Kitty and makes her gradually reassess the shallow world she hitherto inhabited. Only by abandoning her limited space, does she apologise to Walter and proves to be morally superior to him, for it is he who does not cease to cling to a grudge against her. Ultimately, Kitty's resolution to escape her previous life and to open herself to the nuns' influence makes her insightful transformation feasible. It is, however, essential to note that it 
is work which becomes a mutual occupation for both a female and male protagonist, hence it constitutes an available space for any incomer, regardless of their gender. As a matter of fact, there may exist no other sphere which would obviate the dichotomy between Kitty and Walter, the representatives of two opposite gender. It may also strongly suggest that the only way for their achieving harmony is through regarding their own spaces as permeable.

To conclude, the film adaptation of Maugham's The Painted Veil abounds in various transgressions between both female and male spaces. Two genders can exercise their spheres in their own individual way. In the literal sense of space, it seems that isolation may have a detrimental impact on the person enclosed within, as it not only limits their freedom but it greatly hinders their potential growth as well. Indeed, being able to benefit from others with regard to the metaphorical space proves to be inevitable for those whose personalities are flawed. One can either reject and merely abandon their own or simply claim and embrace the other in order to use it to their own advantage. Ultimately, if any transgression implies some beneficial changes between or within spaces, then its realisation follows regardless of gender of its inhabitant.

\section{Works Cited}

Maitzen, Rohan. "A Secret I Am Unworthy to Share? W. Somerset Maugham, The Painted Veil." openlettersmonthly.com, 18 Jan. 2015, www.openlettersmonthly.com/novelreadings/a-secret-i-am-unworthy-toshare-w-somerset-maugham-the-painted-veil/. Accessed 18 Sept. 2016. Maugham, W. Somerset. The Painted Veil. William Heinemann, 1925.

The Painted Veil. Directed by John Curran, performances by Edward Norton and Naomi Watts, Warner Independent Pictures, 2006. 